\title{
FACTORS THAT IMPACT PARENTAL SUCCESS IN SUPPORTING CHILDERN'S DISTANCE LEARNING
}

\author{
Elena Nikolaeva \\ Herzen State Pedagogical University, Russian Federation \\ Elvira Dunaevskaya \\ Herzen State Pedagogical University, Russian Federation \\ Inna Kalabina \\ Herzen State Pedagogical University, Russian Federation
}

\begin{abstract}
Distance learning unexpectedly arrived to Russian schools in March 2020, schools and teachers were not ready for this training type. The aim of present paper is to collect and evaluate parents' view on family preparedness to distance education and on parents' and children' coping with school assignments during the lockdown. 304 parents were interviewed. The data provide evidence that the higher level of parental education is a factor in the efficient distance learning of their children. The higher level of parental education correlates with fewer children in the family, with the time spent by children on home assignments and the number of devices per family member. It was demonstrated that mothers lived through this period more easily than fathers. We found that the parents with a PhD degree provided the most effective support. It could be assumed, that studies at higher education institutions require time management. Having learned this skill, parents with higher education know how to selforganize and teach their children the same. Then, if our schools switch to remote teaching even partially, special guidelines with step-by-step explanations of the material shall be developed for parents. Furthermore, online counselling can be arranged for parents to present the course structure and the sequence of educational activities.
\end{abstract}

Keywords: distance learning, parental support, children, coronavirus, self isolation.

\section{Introduction}

An e-library search for key words "distance learning” brought up 3,834 publications just for 2019 and early 2020 alone. However, with a difference. Publications of 2019 are mostly theoretical in nature and semi-academic in style, while 2020 texts are introduced by alarmist titles like Sudden Distance Learning: the First Month of The Big Rush (Blinov et al., 2020); or Challenges, Problems and Possibilities of University Internationalization under a Force-Major Transfer to Distance Learning (Korolev \& Koroleva, 2020).

Similarly to many other things, distance learning arrived unexpectedly, even though way back in May 1995 the State Committee for Science and Education 
approved The Concept for Establishment and Development of the Single Distance Learning System in Russia (Kvanina, 2005).

Surprisingly, papers on distance learning at primary and secondary school levels are extremely rear (both before and after the coronavirus pandemic) with most of countless publications focused on tertiary education.

\section{Literature Review}

This means that distance learning at schools was never consciously expected and, therefore, its functionality was never set up. The lack of planning resulted in a poorly organized distance learning that schools found themselves in between March and May where all participants were dissatisfied with the process and its outcomes. Things happening at some schools during the recent self-isolation months showed little correspondence to the distance learning concept. Most schools were not equipped for this training type (Terekhova, 2019). However, it was students' parents who turned out the least prepared to deal with the new situation. No one explained to them - prior to, during or, apparently, after the distance learning - what parental support they should provide based on their child's school age.

Well in advance to the pandemic the world was actively discussing new, related but yet different notions: e-learning, web-based learning, online learning, and distance learning. We must differentiate these terms. Mixing them up has led to a hybrid education recently observed at schools. This confusion, perhaps, could be a reason for a failed school year end in the context of teacher/student separation.

Distance learning is an earlier concept. It does not require computers or networks. It is about teacher-student interaction across distances where teacher can guide student's performance. Distance education is usually associated with instructional television broadcasting and courses by correspondence. Now it may also include some educational e-applications. On the internet remote educational interaction is primarily required between teacher and students or among students. A classical distance learning in this context offers direct instructional broadcasting on the internet, videoconferences, chats and scheduled online conferences plus courses or discussions via e-mail (Tsai, Machado, 2002).

Whichever is the case, things happening at national schools March through May are now conventionally called distance learning. It must be highlighted that under The Education Law this learning is not a mode of studies but just a tool and technology to deliver education. And that brings more ambiguity in understanding steps to take and training methods to employ these days.

The Ministry of Education web-site published the following news on the hotline methodological support for distance home schooling: "Over the initial 3 
weeks of school start we have received 8,255 enquiries from educators and parents. 35\% of the enquiries were related to curriculum and duration of on-line classes, the scope of home assignments, and ways to arrange for education without a computer or internet access.

Most phone calls - 80\% - were from parents. They worried that the school shifts onto them some responsibilities for children's education and achievements. They enquired about the maximum scope and timeframes of home assignment. They also asked about the time ratio between explaining new material and unsupervised studies. Many questions were raised by large families where parents struggled with on-line studies for multiple children. Around $40 \%$ of all enquires concerned e-platforms and whether school recommendations for choosing a paid connection to such platforms were legitimate.”

All publishers produce special teacher's manuals for the best use of their textbooks. This time we had a precedent where parents were left without any guidelines on how to support their children who failed to understand teacher's explanations over the internet.

Our review of academic literature has not spotted a survey of parents' attitude towards this training modality and their involvement in children's schooling during the lockdown. It has motivated us to interview patents, to research how they participated in the process and to understand factors promoting a more successful support to children at distance learning.

\section{Methodology}

A google-form was posted with questions about parents' view on family preparedness to distance education and on children's coping with home assignments. The completed questionnaires were submitted from different locations across Russia by 304 parents who volunteered to answer our questions.

Table 1 Distribution of Parents by Age (\%)

\begin{tabular}{|c|c|c|c|c|c|c|}
\hline Age & $\begin{array}{c}\text { aged } 8 \text { to } \\
25 \text { y.o. }\end{array}$ & $\begin{array}{c}\text { up to } 30 \\
\text { y.o. }\end{array}$ & $\begin{array}{c}\text { aged } 31 \text { to } \\
40 \text { y.o. }\end{array}$ & $\begin{array}{c}\text { aged } 41 \text { to } \\
50 \text { y.o. }\end{array}$ & $\begin{array}{c}\text { aged 51 to } \\
60 \text { y.o. }\end{array}$ & $\begin{array}{c}\text { older than } \\
60 \text { y.o. }\end{array}$ \\
\hline $\begin{array}{c}\text { Number of } \\
\text { respondents }\end{array}$ & 1 & 11 & 164 & 120 & 9 & 1 \\
\hline$\%$ & 0.3 & 3.6 & 53.4 & 39.1 & 2.9 & 0.3 \\
\hline
\end{tabular}

Table 1 demonstrates that the majority of parents are between 30 and 50 years. This group has children across different school grades and, therefore, is active in educational support. 
$62.8 \%$ of respondents live in major urban centers, $28.9 \%$ in big cities and the rest in small towns and rural areas.

Table 2 Number of Children in the Family

\begin{tabular}{|c|c|c|c|c|c|}
\hline number of children & 1 & 2 & 3 & 4 & 5 \\
\hline number of responses & 106 & 132 & 45 & 16 & 8 \\
\hline$\%$ & 34.5 & 43.0 & 14.7 & 5.2 & 2.6 \\
\hline
\end{tabular}

Table 2 demonstrates that families predominately have 1 or 2 children (though 4 families had 5 or more children).

Table 3 Age of Children

\begin{tabular}{|c|c|c|c|c|c|c|}
\hline $\begin{array}{c}\text { Age of the } \\
\text { children }\end{array}$ & 0 to 3 y.o. & 3 to 7 y.o. & $\begin{array}{c}7 \text { to } 11 \\
\text { y.o. }\end{array}$ & $\begin{array}{c}11 \text { to } 14 \\
\text { y.o }\end{array}$ & $\begin{array}{c}\text { older } \\
\text { than14 y.o }\end{array}$ & Total \\
\hline $\begin{array}{c}\text { The number of } \\
\text { children }\end{array}$ & 3 & 22 & 155 & 87 & 40 & 307 \\
\hline$\%$ & 1 & 7.2 & 50.5 & 28.3 & 13.0 & 100 \\
\hline
\end{tabular}

In our survey most parents had children at primary and middle schools (Table 3). 36 children of the respondents were 14 to 17 years while 4 children were $17+$ years.

Among parents $76.6 \%$ had a university degree, $2.9 \%$ held an academic title, $14.5 \%$ graduated from vocational colleges while the rest were secondary school graduates.

\section{Results and Dissuasion}

Gadgets available in families are demostrated in Table 4.

Table 4 Gadgets Available in Families

\begin{tabular}{|c|c|c|c|c|c|c|}
\hline The number of gadgets & 1 & 2 & 3 & 4 & 5 & Total \\
\hline Total & 40 & 62 & 72 & 40 & 93 & 307 \\
\hline$\%$ & 13.0 & 20.2 & 23.5 & 13.0 & 30.3 & 100 \\
\hline
\end{tabular}

Obviously over half of respondents (174 persons) reported three or fewer electronic devices in their families. It meant a possibly challenged device availability for parents working from home and 2 children at school. At the same time 93 families owned 5 or more gadgets (most often that number has mandatorily included 1 desktop computer and 1 laptop). Table 5 demonstrates the ratio between the number of gadgets and family members. 
SOCIETY. INTEGRATION. EDUCATION

Proceedings of the International Scientific Conference. Volume V, May $28^{\text {th }}-29^{\text {th }}, 2021.188-198$

Table 5 Distribution of Gadgets in Families

\begin{tabular}{|c|c|c|c|c|c|}
\hline $\begin{array}{c}\text { The number of gadgets } \\
\text { per person }\end{array}$ & 1 & 2 & 3 & 4 & Total \\
\hline Total & 195 & 73 & 24 & 15 & 307 \\
\hline$\%$ & 63.5 & 23.8 & 7.8 & 4.9 & 100 \\
\hline
\end{tabular}

Table 5 clearly shows that most respondents were able to provide their children with a gadget. In 73 families (23.8\%) one device was shared by 2 siblings, in 24 families (7.8\%) by 3 family members, and in 15 families (4.9\%) by 4 persons.

$55.9 \%$ of families had a desktop computer while $44.1 \%$ did not. At the same time $78.3 \%$ of families had a laptop.

It is worth mentioning that 17 out of 304 respondents reported having neither desktop computer, nor laptop, nor tablet (5.6\%). All of these people lived in small towns or rural areas and had tertiary education (46.7\%) or secondary/vocational secondary education (the rest). One third among these 17 respondents had no internet connection at their domicile. Only 6 respondents received tablets from school for education. This immediately brings to mind an article titled Contemporary Informational Technologies at Russian Schools (Ivanko et al., 2019) whose optimism goes beyond the reported figures.

In the survey $64.2 \%$ of all families reported receiving an extra tablet for education. However, these were predominately families in metropolitan areas.

In 12 families (or $3.9 \%$ ) a single tablet was shared by all family members. These families were from the Small Town/Rural Areas Group. Among them 4 families also had no internet access. At the same time 9 parents reported receiving extra device from the school. In this respect a statement by E. V. Scherbakova and T. N. Scherbakova (2019) - that rural schools must join into the global educational network rather than being outcasts - seems strongly relevant.

$19.7 \%$ of families stated that their children have no dedicated space for studies at computer. It is worth mentioning that $63.8 \%$ of parents also worked fulltime.

91.8\% of surveyed parents think that distance learning is temporary. They fail to understand that the entire world switches to complex education wherein distance learning is an integral component. This said, $36.2 \%$ think that the recently experienced teaching modality is a rehearsal for a wider practice of distance learning.

Next we enquired about the scope of adult support children needed with their home assignments. Parents were asked to review their time use and evaluate how much of it was spent on children's questions and requests to help with studies (Table 6). 
Table 6 Child's Dependence on Parental Assistance During Education (parent's evaluation of resource \% spent by him/her on a child)

\begin{tabular}{|c|c|c|c|c|c|}
\hline $\begin{array}{c}\text { parent's } \\
\text { evaluation of } \\
\text { resource }\end{array}$ & $\begin{array}{c}\text { from } 0 \text { to } \\
10 \%\end{array}$ & $\begin{array}{c}\text { from } 11 \text { to } \\
30 \%\end{array}$ & $\begin{array}{c}\text { from } 31 \text { to } \\
50 \%\end{array}$ & $\begin{array}{c}\text { from } 51 \text { to } \\
100 \%\end{array}$ & Total \\
\hline $\begin{array}{c}\text { Number of } \\
\text { responses }\end{array}$ & 46 & 36 & 63 & 162 & 307 \\
\hline$\%$ & 15 & 11.7 & 20.5 & 52.8 & 100 \\
\hline
\end{tabular}

Table 6 demonstrates that a large portion of parents actively participate in assisting their children with homework. This is new in comparison to regular school days where many parents would only check the outomes rather than continously coach their children during the process.Table 7 pictures parental assessment of how much time their child spent on homework.

Table 7 Time Spent by Children on Home Assignments as Estimated by Parents

\begin{tabular}{|c|c|c|c|c|c|c|c|}
\hline Time (in ours) & 1 & 2 & 3 & 4 & 5 & $\begin{array}{c}\text { All the } \\
\text { day }\end{array}$ & Total \\
\hline $\begin{array}{c}\text { Number of } \\
\text { responses }\end{array}$ & 22 & 42 & 48 & 44 & 48 & 103 & 307 \\
\hline$\%$ & 7.2 & 13.7 & 15.6 & 14.3 & 15.6 & 33.6 & 100 \\
\hline
\end{tabular}

As seen in Table 7 most of the "enitier day" assessments given by parents may indicate their frustration and, therefore, diverge from reality. It rather shows their tiredness of nonstop involment into children education. Futhermore, we wanted to determine factors that could facilitate an efficient distance learning and effective parental support.

We assumed that parents' own education could be among decisive factors. Any studies require structured time management and limitated freedom in one's time use. Moreover, the higher level of one's education is, the more structured his/her day should be to perform increased tasks. It is conceivable that parents who mastered time management may teach this skill to their children.

\section{The Assessment Based on Education Level}

In this surveay parents with secondary education predominately were under 30 years (10 out of 18). Most of these 18 parents lived in small towns or villages. 3 families had no gadgets at all. Only 33.3\% lived in big cities. On average, a family had 2.6 children though $33.3 \%$ of families had $4+$ children. Half of the respondents in this group ( 9 parents) could not work from home under the lockdown. The group had 3.3 gadgets per family. 7 families shared 1 device per 
2 children while 2 families had just 1 gadget per 4 kids. However, parents reported that almost all of them received tablets provided by schools.

Only 4 parents (22.2\% ) claimed that children managed school homework independently and required almost zero adult assistance. Half of all respondents reported that children needed an active parental involvement and that it took between $50 \%$ to $100 \%$ of parents' time. Practically all parents thought that distance learning was a temporary measure rather than a rehearsal of a future education modality. Parents insisted that children spent 4 to 5 hours to do homework (3 parents wrote that it took an entire day). Already 5 respondents believed that children sat all day long in front of their computers. "Sleep" and "TV" were named a key recovery and leisure method.

Here is a typical exapmle. A single parent household where mother of 34 years has two children (daugter, 7 y.o., $1^{\text {st }}$ grader and son, 12 y.o., $5^{\text {th }}$ grader). The mother has not been working since the lockdown onset. The family owns 1 laptop. Therefore, children cannot attend on-line classes simultaneously. Enquires were made to classmate parents asking for details of homework given and topics explained. The mother was panic-stricken and suffered from headaches; her temperature rose. When family's broken tablet got repaired, her condition improved.

40 parents had vocational secondary education. $40 \%$ of this subset was aged $40+$. On average, a family had 2.6 children, similarly to the previous group, and owned 3.2 devices. 5 families out of 40 had no gadgets at all, and 1 family had only a single tablet. In 13 families out of 40 two family members shared 1 gadget, while 4 families had 1 gadget per 4 persons. Only 3 children had no dedicated personal work space.

In this group $20 \%$ of parents claimed their children's capability to do homework on their own while $80 \%$ responded that children constantly asked for help. Only 18 parents out of 40 worked during the lockdown which meant that more than half of parents were always at home. 35\% of parents responded that children worked on home assignments all day long. One mother - who insisted that her children spent all days on homework - describes her time-off: "I go to our kitchen and close the door for privacy, make myself a cup of strong tea and enjoy half an hour of quietness and rest". Other mom whose children similarly spent a full day on homework wrote: "Having helped my kids with all home assignments and after my remote work done I have time left for sleep only." A mom whose children complete their school assignments in 2 hours wrote: "Great, I left my job and stay at home to supervise my kids! They will not perform without my supervision.” (sic)

Finally, the third subset of 232 persons had higher tertiary education. An average family raised 1.8 children (that is fewer compared to groups with less education). Predominantly they live in big urban centers. With regard to the age 
breakdown: in 51 families parents were under 30 y.o.; 125 families between 31 and 40 years; 55 families up to 50 years; 4 families older than 50 years; and 1 family older than 60 years.

7 families out of 232 had no gadgets at all (3\%). 4 families owned 1 tablet. On the whole, in comparison to parents without higher education this group was significantly better equipped with gadgets, primarily with desktop computers and laptops (3.2 devices per family and most families had 1 child only). In $22.8 \%$ of families one device was shared by 2 persons, $8.6 \%$ - by 3 persons, and $4.3 \%$ (10 families) - by 4 persons. In the rest of families every member had a personal gadget.

Due to the group's big size we identified 3 subgroups based on parents' age: under 30 years (51 persons), 30 to 40 years (121 persons) and over 41 years (59 persons). Families without any gadgets were equally represented across all subgroups. In the youngest subgroup 33.3\% of parents did not work; in the midaged subgroup - $37.2 \%$, while $20.3 \%$ of parents did not work among $41+$ years parents.

23.5\% of young parents (under 30 y.o.) with higher education claimed that their children do everything independently, though evidently they raised primary schoolers.

The 30 to 40 year group of parents with higher education viewed distance learning of their children basically the same way and claimed that $23.9 \%$ of children studied without supervision. Parents older than 40 y.o. proved to be more prepared to the situation plus they had older children. They responded (43.1\% of parents) that children did not require much of their attention. This parameter is significantly different under Wilcoxon's test and distinguishes this subgroup from others. Parents in this subgroup more frequently demonstrated creative ways of recovery: they practiced sports and listened to music. Younger age parents in this group responded that they danced and exercised. The 30 to 40 year subset insisted on sleep as a general recovery method.

One answer was especially emotional and claimed that the child studied all day long. In fact, no child can sustain such lengthy studies. Probably, this response indicates parental tiredness and irritation. This response resonated with younger parents in $27.5 \%$ of cases, with $37.2 \%$ of parents in the 30 to 40 year subgroup and with $38.9 \%$ of more senior parents. The two latter age subgroups demonstrated a significant difference versus the youngest subgroup $(p \leq 0,05$, Wilcoxon's test).

Thus the, highest level of parental frustration is in the higher education parental group of 30 to 40 years (their children require more time for home assignments which felt as if they studied all day long). It could be due to the school age most challenging for distance learning. If younger parents presumably raise preschoolers and more senior parents (50+ years) have high schoolers (who can 
regulate the time they spent at computer), the 30 to 40 year subgroup is more likely to support middle school students with a minimal motivation for studies (Nikolaeva et al., 2017). Younger parents rarely claim that their children study full days while older parents complain less about children's need for their constant attention.

11 of survey respondents had an academic title. Among title holders one father had 5 children. Though during the lockdown he did not work from home, his entire day was spent on helping his children study. In this family every child had a personal gadget but no dedicated work spot. Emotionally, this dad felt that his kids worked on home assignments and looked at their screens an entire day. He had no doubts that distance learning was temporary. To a question about his ways of regaining energy he provided a short answer: I drink beer.

The most optimistic outlook onto the situation was registered in 10 mothers who had academic titles, mostly aged between 31 and 40 years. $40 \%$ of them claimed that children operated on their own. An average family had 1 or 2 children and owned 4.2 gadgets. Only in one family a child had no dedicated work space $(10 \%) .8$ mothers in this subset worked full time as school or university educators. However, only 4 responded that their children required continuous assistance. Most moms believed that children coped on their own. They estimated that children completed home assignments within 1 to 3 hours and sat in front of their computers relatively the same time. They were also sure that distance learning is by no way temporary (9 out of 10) and will be extended for a longer period.

\section{Factor Analysis of the Data}

Factor One includes with greater weights children's age and their need for parental assistance with homework (with a negative sign). It means that the older children are, the less assistance they need from parents. Factor Two featured with greater weights parental education and number of children in the family (with a negative sign). Thus, the higher level of parent education correlates with fewer children in the family. Factor Three embraced the age of parents and place of domicile. This can be expressed as: the older parents are, the higher the probability is of them living in a major city. Lastly, Factor Four included time spent by children on home assignments and number of devices per family member. The outcome is very predictable as fewer gadgets meant more time spent by children on homework.

Table 8 features factor analysis of the data. Kaiser-Meyer-Olkin Measure of Sampling Adequacy is 0.540 and testifies to the data fitness for use. A 4-factor solution is obtained. Explained variance is $65.3 \%$. 
Table 8 Rotated Component Matrix ${ }^{a}$

\begin{tabular}{|c|c|c|c|c|}
\hline & \multicolumn{4}{|c|}{ Component } \\
\hline & 1 & 2 & 3 & 4 \\
\hline Age of children & .853 & .120 & .019 & .179 \\
\hline $\begin{array}{l}\text { How would you assess your child's need for } \\
\text { parental assistance during homework? }\end{array}$ & -.698 & -.012 & .038 & .464 \\
\hline Your own education level & -.030 & .771 & .137 & .043 \\
\hline Number of children in the family & -.174 & -.770 & .108 & .125 \\
\hline Your age & .185 & -.154 & .814 & -.025 \\
\hline Where do you live? & -.192 & .213 & .746 & -.034 \\
\hline $\begin{array}{l}\text { How much time did your children spend on } \\
\text { doing home assignments? }\end{array}$ & .187 & .085 & .038 & .840 \\
\hline $\begin{array}{l}\text { How many devices does your family have per } \\
\text { person? }\end{array}$ & .225 & .179 & .110 & -.524 \\
\hline
\end{tabular}

Extraction Method: Principal Component Analysis; Rotation Method: Varimax with

Kaiser Normalization;

a. Rotation converged in 5 iterations.

\section{Conclusions}

In summary, our data provide evidence that the higher level of parental education is a factor in efficient distance learning of children. It could be assumed, that studies at higher education institutions require time management. Having learned this skill, parents with higher education know h ow to self-organize and teach their children the same. They have more gadgets in the family and almost always own a computer. All of the above enable their children to complete assignments faster and more efficiently. These parents raise fewer kids and, therefore, are more available to their children. Finally, they can better understand school assignments and provide competent answers to child's questions.

To conclude, if our schools switch to remote teaching even partially, special guidelines with step-by-step explanations of the material shall be developed for parents. Furthermore, online counselling can be arranged for parents to present the course structure and the sequence of educational activities.

\section{References}

Blinov, V.I., Sergeev, I.S. \& Esenina, E.YU. (2020). Sudden distance Learning: the first month of the big rush (based on the results of an express study and polls). Professional'noe obrazovanie i rynok truda, 2, 6-33.

Ivanko, A.F., Ivanko, M.A. \& Romanchuk, E.E. (2019). Modern it-technologies in schools of Russia. Nauchnoe obozrenie. Pedagogicheskie nauki, 1, 25-28.

Kvanina, V.V. (2005) Distance learning in Russia as the fact of reality. Pravo i obrazovanie, 5, 61-68. 
Proceedings of the International Scientific Conference. Volume V, May $28^{\text {th }}-29^{\text {th }}, 2021.188-198$

Korolev, K.YU. \& Koroleva, N.G. (2020). Challenges, problems and prospects of internationalization during force majeure switch to distant teaching and learning at high schools. Primo aspectu, 2 (42), 76-81.

Nikolaeva, E.I., Strekosova, V.S. \& Zinovjeva, I.I. (2017). The relation of educational success with the psychological characteristics of 4-7 grade students (longitudinal study). Liberal Arts in Russia, 6 (5), 404-408. https://doi.org/10.15643/libartrus-2017.5.5

Shcherbakova, E.V. \& Shcherbakova, T.N. (2019) The use of modern information and computer technologies in educational process of rural small schools. Azimut nauchnyh issledovanij: pedagogika i psihologiya, 8, 1 (26), 305-307.

Terekhova, E.YU. (2019). Current problems of distance learning in Russia. Dopolnitel'noe professional'noe obrazovanie v strane i mire, 5(47),10-12.

Tsai, S. \& Machado, P. (2002). E-learning, online learning, language learning, or distance learning: Unveiling the ambiguity in current terminology. Association for Computer Machinery eLearn Magazine, 7, 3-5. https://dl.acm.org/doi/10.1145/566778.568597 